\title{
The Post-Graduate Academic English Language Skills and the Language Skills Measured by the Iranian PhD Entrance Exam: A Test Reform and Curriculum Change
}

\author{
Shiela Kheirzadeh (D)1, S. Susan Marandi (iD) 2,, Mansoor Tavakoli (iD) 3 \\ ${ }^{1}$ Assistant Professor of TEFL, Alzahra University, Tehran, Iran \\ ${ }^{2}$ Associate Professor of TEFL, Alzahra University, Tehran, Iran \\ ${ }^{3}$ Professor of TEFL, University of Isfahan, Isfahan, Iran
}

\section{ARTICLE HISTORY}

Received: 15 October 2018

Revised: 11 December 2018

Accepted: 02 January 2019

\section{KEYWORDS}

Congruence,

Field-specialist informants, Language-specialist informants, Academic skills,

Post-graduate students,

$\mathrm{PhD}$ entrance exam

\begin{abstract}
To investigate the congruence between the requisite postgraduate academic language skills and the language skills measured by the General English section of the Iranian National PhD Entrance exam, fieldspecialist informants, language-specialist informants and post-graduate students were questioned. The informants' data were collected through interviews and the students' data were obtained through a language skills' questionnaire. The informants and students' data were analyzed through content analysis and frequency analysis, respectively. The informants acknowledged that all four language skills were crucial for academic success. Considering congruity, both groups of informants asserted that there was little congruity between the language skills measured by the exam and those of the academic context. Post-graduate students believed that the reading section of the exam did not match their academic needs; they also believed that a writing section should be added and that a listening section need not be included in the exam. The findings have some implications for a change in the curriculum preceding the exam.
\end{abstract}

\section{INTRODUCTION}

Tests are commonly used for the purpose of making decisions such as selecting the right person for a job, awarding a certificate and entering a higher level of education (Zahedi \& Shamsaee, 2012). If the consequences and the decisions made by the testing program are serious and affect a large group of people, the test is called high-stakes. The exact identification of test purpose and use are principal prerequisites for test development, especially in the case of high-stakes tests. Thus test developers need to consider, "for what purpose the test will serve, what underlying construct will be applied, who will take the test, and how it will be used and by whom" (Spaan, 2006, p. 71). Therefore, test designers need to consult the stakeholders to decide on test content and specifications. In other words, they should decide what language skills should be measured by the test and whether they should be measured integratively or discretely

CONTACT: S. Susan Marandi $\bowtie$ susanmarandi@alzahra.ac.ir University, Tehran, Iran

Associate Professor of TEFL, Alzahra 
(Spaan, 2006). According to Ryan (2002), the criteria to decide about the test content and purpose comes from a variety of resources, including the construct itself, various stakeholders, and existing research. In order to produce a language test that appropriately measures the academic language needs of the students, a detailed and precise analysis of the construct needs to be carried out (Butler et al., 2004). As stated by Berendes et al. (2018), academic language is the language used to transfer and acquire knowledge whether in spoken academic settings or in school textbooks. Ryan (2002) also suggests consulting stakeholders to decide about the assessment interpretation or test use to assure that the test is measuring what the students know and need. These stakeholders are teachers, students, parents or anyone involved in the educational system.

What can be inferred from the above mentioned points is that there must be congruence between what a test is measuring and the needs of the test takers, especially in the case of high-stakes tests. If the test results are used to decide on whom to accept for further studies at a higher educational level, ensuring the congruence between the academic language needs of the students and the needs of the test is imperative.

\subsection{English for Academic Purposes (EAP)}

English for Academic Purposes (EAP) was a terminology coined by Johns in 1974 (Hyland, 2006). EAP, according to Hyland, "attempts to offer systematic, locally managed, solutionoriented approaches that address the pervasive and endemic challenges posed by academic study to a diverse student body by focusing on student needs and discipline-specific communication skills" (p. 4). Scarcella (2003) believes that learners must develop an advanced level of proficiency in all language skills to have successful "discipline-specific communication." According to him, academic English is not limited to the reading skill, and learners should be able to use words in written and spoken communications, as well.

According to Gottlieb and Ernst-Slavit (2013), academic language or academic English is a register, a variety of language for a special group of audience in a specific context. In other words, academic language is characterized by specific linguistic features, discourse features, grammatical structures and vocabulary for a specific discipline. Chamot and O'Malley (1994) define academic language as "the language that is used by teachers and students for the purpose of acquiring new knowledge and skills" (p. 40). This is a rather general definition of academic language; however, attempts have been made to define academic language in a narrower sense, focusing on language functions, register, use and cognitive difficulty (e.g., Scarcella, 2003; Solomon \& Rhodes, 1995). Moreover, the recent focus has been on language specific to special academic contexts such as English for engineering, social sciences, etc. (Gottlieb, 2004).

According to Saville-Troike (1984) and Swales (1990), target academic English language tasks mainly consist of research projects, summaries, writing critiques, note-taking in lectures, and reading abstracts and reports, all of which have their own genres. Scarcella (2003), citing Swales (1990), points out that target academic English tasks include "reading abstracts, getting down the key ideas from lectures, and writing critiques, summaries, annotated bibliographies, reports, case studies, research projects, expository essays" (p. 9). Dudley-Evans and St John (1998, p. 41) list the following tasks as the core academic tasks:

- Listening to lectures

- Participating in supervisions, seminars and tutorials

- Reading textbooks, articles and other material

- Writing essays, examination answers, dissertations and reports

A huge portion of the university work, especially in an EFL (English as a Foreign Language) context, is devoted to reading. Therefore, many EFL learners gradually acquire advanced 
reading skills despite the fact that they do not demonstrate the same progress in oral communication skills (Huang, 2006; Shafie \& Nayan, 2011). Reading, as stated by Flowerdew and Peacock (2001) and Grabe and Stoller (2011), is composed of macro- and micro-skills. Using the existing knowledge or background schemata to decipher the new information and knowledge is an example of a macro-reading skill. As stated by Grabe (2009), readers form their interpretation of the text by focusing on their feeling about it and whether it relates or contradicts background knowledge. In other words, they integrate text information with other ideas developed from their background knowledge and interpret it based on such background knowledge. Generalization, recognition, and finding logical relations are examples of microreading skills. Word recognition is considered the most important factor in successful reading since it is not possible for readers to comprehend without being able to recognize words quickly and accurately and being sensitive to orthographic, phonological, and semantic usages (Grabe, 2009; Kuzborska, 2010)

Studies by Durkin (2004) and Reid, Kirkpatric and Mulligan (1998) indicated that non-native English learners need to spend twice or three times longer than native speakers to finish reading a passage; therefore, forming the habits of critical reading for academic purposes is much harder.

Though Shelyakina (2010) and Grabe and Zhang (2013) highlight the strong connection between reading and writing tasks, writing is considered as a major problem for students (Leki \& Carson, 1994; Rosenfeld et al., 2001; Zhu \& Flaitz, 2005). Bridgeman and Carlson (1983) investigated the beliefs and practices of academic writing. Their main findings were (a) at the graduate level, writing is the prime skill; (b) even for the disciplines in which writing was not of great emphasis, students were required to have writing assignments from the first year of college; (c) the type of required writing skills varied from discipline to discipline; (d) the assessment criterion was discourse, rather than word or sentence, and finally, (e) non-native speakers had more problems at the word or sentence level compared with the natives. Canseco and Byrd (1989, p. 308) list "examinations, problems and assignments, projects, papers, case studies, reports and miscellaneous writing assignments" as the seven categories of writing assignments of college students. Finally, Saville-Troike (1984) concluded that "the language skill which is most likely to develop ... [academic] competence is writing" (p. 217). To achieve academic success and to present the academic skills, quality writing is imperative. Besides writing, oral communication skills are of utmost importance.

Berman and Cheng's (2001) needs analysis of graduate and undergraduate students indicated that academic oral communication skills such as presentation or class discussions are the most difficult for L2 students. Forey and Feng (2016) stressed the importance of "teaching interactive, interpersonal features that help speakers engage with their audiences" (p. 428). Cheng, Myles and Curtis (2004) found that L2 graduate students had the most problems in speaking and writing skills. Ostler (1980) and Morell (2007) state that ESL (English as a Second Language) students are in need of help in developing academic speaking abilities such as talking with their instructors; she proposes that, "graduate [ESL-EAP] classes might need to include one unit on preparing and giving talks and another on preparing for and participating in panel discussions" (p. 501).

Listening is the most challenging skill for L2 (Second Language) learners, even the highly proficient ones (Mason, 1995, as cited in Ferris \& Tagg, 1996; Field, 2011). Olster's (1980) participants stated that every day listening and conversations were much easier for them than the classroom context conversations. Furthermore, Kim (2006), asserts that students with high scores in TOEFL test are not necessarily skillful enough in academic listening skill; she claims that academic listening has its own specialties, totally different from those of everyday listening. And finally, according to Benson (1989, p. 441), what is necessary is "listening to 
learn" as opposed to "listening to comprehend." In other words, academic listening is listening for meaning and understanding, and not the mere decoding of the language (Rost, 2011).

\subsection{English for Academic Purposes (EAP), assessment and curriculum}

In an applied field of study such as language testing, the outcome of research into actual assessment designs and uses should model development for theories of measurement of language skills and building theories and models of language learning and use in target situations such as academic contexts (Schmitt \& Hamp-Lyons, 2015). Though local EAP assessment, compared with standardized exams such as TOEFL, is an attempt to create a balance between assessment and the specific context, it can never fully represent what Bachman and Palmer (1996) call the target language use (TLU) domain. But since it has a closer connection with EAP teaching in that specific TLU context, it has the potential to better represent the construct of academic language skills. Therefore, the EAP and academic language testing communities can improve their understanding of students' learning needs and the construct of EAP through cooperation in designing and developing EAP tests.

As stated by Schmitt and Hamp-Lyons (2015), if EAP assessments are to be used to make highstakes decisions about candidates' readiness to progress to university or to graduate, it is important for those designing and developing such tests to arrive at the right level of authenticity; that is, "the degree of correspondence of the characteristics of a given language test task to the features of the TLU task" (Bachman \& Palmer, 1996, p. 23). What can be implied from the definition of authenticity is that what students need at TLU domain, including language skills and abilities, should be reflected in the test. However, a point worth mentioning here is that the practical considerations of developing and administering large scale standardized proficiency exams or local ones mean that these are by their very nature reductionist; they narrow the educational curriculum. Curriculum narrowing (Nichols \& Berliner, 2005, 2007; Watanabe, 2007) means limiting the educational curriculum through prioritizing some skills or abilities at the expense of others; for example, in the case of the General English section of the $\mathrm{PhD}$ Entrance exam in Iran, the academic reading skill is prioritized, which may underrepresent the construct of academic skills.

Therefore, the level, importance and difficulty of different target language academic skills crucial for academic success may vary, and carrying out a situation-specific study may help ensure the congruence between academic task and test task (Educational Testing service, 1990). The present paper reports the findings of a study which focuses on the following research questions:

1. Which academic English language skills are considered by field-specialist and languagespecialist informants to be important for post-graduate students? And is there any congruence between these viewpoints and the language skills actually measured by the General English section of the Iranian National PhD Entrance exam?

2. Which academic English language skills do post-graduate students consider to be important? And is there any congruence between these viewpoints and the language skills actually measured by the General English section of the Iranian National PhD Entrance exam?

Before proceeding to the method section, a brief description of the PhD Entrance exam, the General English section, as the main concern of the present study, seems crucial. The General English section includes Grammar, Vocabulary and Reading sub-sections respectively. In the reading part, different reading skills such as guessing meaning from context, inferencing, finding main ideas, finding supporting details and making generalizations are measured. It should be mentioned that this exam is annually held and all the $\mathrm{PhD}$ candidates in all disciplines sit for it, though the post-graduate courses in Iran are commonly held in Persian and English is mainly used for supplementing the readings. 


\section{METHOD}

A total number of 183 participants took part in the data collection phase of the study. These participants were divided into three groups: The first group consisted of twelve field-specialist informants (faculty members of Humanities, Basic Sciences and Engineering departments) in different academic disciplines of Humanities (namely, History, Persian Literature, Geography and Psychology) ( $n=4)$, Basic Sciences (namely, Mathematics and Statistics, Chemistry, Biology and Physics) ( $\mathrm{n}=4)$ and Engineering (namely, Computer Software, Electronic, Information Technology and Mechanics) $(n=4)$ who were selected through purposive sampling from four public universities in Iran. The field specialist informants (as well as the language specialist informants) were selected from among those who were familiar with the Iranian National PhD Entrance Exam and had the experience of working with post-graduate students.

The second group consisted of five language specialist informants, meaning faculty members of English language departments. They were selected through purposive sampling from four public universities in Iran. The criteria for their selection were familiarity with the General English section of the Iranian National PhD Entrance Exam and experience in teaching at the post-graduate level.

The third and last group consisted of 166 post-graduate ( $\mathrm{PhD}$ level) students (male and female) of seven major public universities in Iran, with an age range of 25 to 50, and majoring in Humanities $(n=86)$, Basic Sciences $(n=44)$ and Engineering $(n=36)$. The post-graduate participants were those who had passed the PhD Entrance Exam and had been accepted by one of the public universities in Iran to further their studies at the PhD level. To ensure the generalizability of the findings, the participants were randomly selected from public universities in Iran in the three major academic disciplines including Humanities, Basic Sciences and Engineering.

\subsection{Instruments}

\section{Interview questions}

Five researcher-made interview questions were posed to check the congruence between the academic language skills needed for post-graduate students and those required for the General English section of the Iranian National PhD Entrance Exam (See Appendix A). These questions sought to uncover which language skills that are more important in different disciplines; whether these skills match the skills measured by the PhD Entrance exam; the reason of not including some of the skills, if any, in the exam, from their viewpoint, and finally whether the degree of the importance of skills differs across the three major academic disciplines, namely, Humanities, Basic Sciences and Engineering. The interview questions revolved around the four main language skills were developed referring to the literature, namely Saville-Troike (1984), Swales (1990), Dudley-Evans and St. John (1998) and Scarcella (2003) and were piloted on a similar group and revisions were made in the wording and order of presentation. The interviews were administered in Persian and were recorded for further analysis.

\section{Language skills questionnaire}

A questionnaire with 3 multiple-choice items and 8 open-ended items was designed to discover the post-graduate students' opinions about the academic language skills they need (six items) and the ones measured by the General English section of the Iranian National PhD Entrance Exam (five items) (See Appendix B). It should be mentioned that the questionnaire was constructed based on the literature on different definitions of academic English needs and skills proposed by scholars such as Saville-Troike (1984), Swales (1990), Dudley-Evans and St. John (1998) and Scarcella (2003). The questionnaire was developed in the post-graduate students' first language, Persian and was piloted on a similar group of participants. 


\subsection{Procedure}

For the interview section of the research, both language specialist and field specialist informants were informed about the purpose of the research and their consent for participation was obtained. As stated above, the criterion for selecting these informants was their familiarity with the $\mathrm{PhD}$ Entrance Exam and the experience of teaching and working with post-graduate students in different disciplines. The face-to-face interviews were carried out in the language specialist and field specialist informants' offices in university and were recorded for further analysis. After the data collection, all the interviews were transcribed and translated into English to find answers to the questions. The questionnaire was distributed manually or through e-mail, and the participants were promised the confidentiality of the responses.

\subsection{Data analysis}

The questionnaire data were analyzed through frequency analysis conducted by SPSS, version 23 and the interview data were analyzed by content analysis in terms of codes and emerging themes.

\section{RESULTS}

The first research question of the study sought the important academic language skills at postgraduate level, and whether those skills have been appropriately measured by the Iranian National PhD Entrance Exam, the General English section.

The following are the ideas of the field-specialist and language-specialist informants about language skill(s) that are crucially important for a post-graduate student. The main points stated by these specialists are as follows.

- "The four language skills are of equal importance and none can be considered as the most significant. They can be compared to the four pillars of a firmly-built house: the removal of any one would undoubtedly lead to the collapse of the house." (Humanities specialist)

- "Post-graduate students need to be able to read field-specific books in English and write their papers in English to share their findings with their academic community." (Humanities specialist)

"The most important skill at the post-graduate level is reading; however, there is no need for listening in the Iranian context." (Humanities specialist)

- "All skills are important; however, speaking, listening and writing are more significant, respectively. Nearly all PhD students are conversant with reading; therefore, there is no need to measure reading in the PhD Entrance Exam. "(Basic Sciences specialist)

- "Reading and writing are the most notable ones; however, students need to be able to present in classes or conferences, which requires a good command of oral communication skills." (Basic Sciences specialist)

- $\quad$ "Reading and writing along with a good command of grammar and field-specific terminologies are imperative." (Engineering specialist)

- "Reading and writing have the highest priority, respectively. Listening and speaking are necessary only if PhD students want to take sabbatical leave abroad." (Engineering specialist)

- "Reading and then writing are more important. A PhD student is expected to read and write professionally in his own field." (Language specialist)

- "Reading, writing and the proper mastery of vocabulary, especially lexical bundles, is imperative." (Language specialist) 
The other issue of interest was whether the academic language needs of $\mathrm{PhD}$ students in the three abovementioned disciplines differ. The field-specialist informants, except for two, mentioned that there was no difference among the disciplines considering their academic needs. In other words, all four skills are important to all academic disciplines. Of those two informants who disagreed, one of them (from an Engineering background) stated that Engineering students feel a stronger need for English as they are dealing with technology and empirical sciences. The other informant (with a Humanities background) referred to the effect of culture on the humanities, which makes writing in a foreign language harder. In other words, transferring culture-bound thoughts and beliefs truly and exactly to another language with no common cultural background was felt to be more complicated than transferring information in a culturefree field of study such as Engineering.

The language-specialist informants, in general, believed that there was no substantial difference in the English language needs of the various academic disciplines and how they should prioritize the language skills across the three academic disciplines; at the same time, however, they claimed that Humanities students need to have a wider scope of discourse knowledge and that the academic language of the Engineering group is more symbolic and concrete while the language of the Humanities is more abstract and conceptual.

The last question was to find the field-specialist and language-specialist informants' opinions concerning the congruence between the skills measured by the General English section of the $\mathrm{PhD}$ Entrance Exam, mentioned above, and the skills that are essential for success at the $\mathrm{PhD}$ level. The opinions of the three groups of the informants are as follows.

- "There is no congruence between the skills measured by the exam and the skills that are crucially important for PhD candidates. The reading passages and the vocabulary section have no bearings on their academic needs. Writing is of vital importance to a PhD candidate; however, it is not included in the exam. The reason might be that we should not test something in which we haven't invested time and effort teaching it to graduate or under-graduate students." (Humanities specialist)

- "There is no congruence between the skills measured by the exam and the skills that are crucially important for PhD candidates. There is no academic justification or theory to support the exam design and specification." (Humanities specialist)

- "PhD candidates really need writing skills; however, this skill is not included in the exam because of the scoring complexity. In general, the exam does not match the academic needs of PhD candidates." (Basic Sciences specialist)

- "The exam is not standard. It can be replaced by standard exams such as academic IELTS. The PhD students who are accepted in universities based on this exam are not competent in English." (Basic Sciences specialist)

- "There is no congruence between the exam and learners' academic needs. It is just an imitation of world-famous proficiency tests. The reading section is acceptable to some extent, but not that relevant. It is highly recommended to add writing and listening skills to the exam." (Engineering specialist)

- "The exam needs to be improved. A writing section must definitely be included in the exam, even if it is costly and time consuming to score and administer." (Engineering specialist)

- "The exam focuses only on reading and vocabulary, and this does not match the academic needs. The reason might be that measuring other language skills like writing and listening is difficult if not impossible." (Language specialist)

- "The focus is on language components (grammar and vocabulary). The subordinate role given to the essential language skills might be due to the design and evaluation complexities. However, excluding the language skills renders the exam invalid." (Language specialist) 


\subsection{Post-graduate students}

The second research question of the present study explored the post-graduate students' own opinions about the academic language skills that are crucial to their academic success, and whether these skills were included in the General English section of the PhD Entrance Exam. Six out of the eleven items in the questionnaire dealt with the academic language skills, the results of which are presented below.

The first item of the questionnaire asked the post-graduate students to rank the four language skills based on their importance at the $\mathrm{PhD}$ level. Based on the result of the ranking, checked by the Friedman Test, the mean ranks indicated that reading (1.84), writing (2.31), listening (2.91) and speaking (2.94) were ranked from the most important to the least important, respectively.

The second item asked the students to indicate their most frequent use of the writing skill. The results indicated that writing articles $(64.05 \%)$ was the most important writing need for Iranian post-graduate students. Writing emails and online correspondences with professors, researchers and post-graduate students abroad is the second most felt need $(20.70 \%)$ followed by translating their papers and research findings from Persian into English $(5.29 \%)$, writing theses and proposals in English (5.29\%), report writing (2.88\%) and preparing PowerPoint slides for classroom and conference presentations $(2.40 \%)$. The third questionnaire item sought to uncover their most frequent use of the reading skill. As may be seen in Table 1, the most important academic reading need was considered to be reading scientific articles $(48.81 \%)$ to learn about the recent trends in research findings. Reading books (35.32\%), different scientific texts $(6.34 \%)$, websites $(5.59 \%)$, theses and abstracts $(2.37 \%)$ and finally reading newspapers $(1.18 \%)$ were ranked next, respectively.

The main academic listening needs of the post-graduate students were as follows. $25.25 \%$ of the post-graduate participants of the present study mentioned that they required this skill to benefit from lectures and conference presentations. However, the same percent $(25.25 \%)$ of the participants stated that they do not need English listening comprehension in their current academic contexts. Listening to and understanding talks and conversations while traveling abroad for the sabbatical leave, for instance, were ranked as the third most frequent (19.77\%). Understanding films and documentaries related to their own disciplines (18.32\%), news (7.92\%) and online courses and classes $(3.46 \%)$ were ranked next, respectively. Finally, the post-graduate students were asked about their need for English speaking skills in their current context. The two main academic speaking needs which were of nearly equal importance to the participants of the present study were presenting in international conferences and seminars (36.68\%), and conversing and interacting with professors, researchers and post-graduate students abroad $(36.48 \%)$; however, $30.68 \%$ of the participants stated that they do not need speaking in their current academic life (Table 1).

The last item concerning the academic needs of the post-graduate students required the participants to rank the eight listed academic skills (See Appendix B) based on their importance. The result of the Friedman Test indicated that the mostly required academic skill was writing abstract followed by writing articles, academic presentation, note-taking in lectures, writing critiques and summaries. Discussion and writing reports were ranked as the least felt needs in the academic context.

While the first six items of the questionnaire investigated the academic language needs of $\mathrm{PhD}$ students, the next five items examined whether the current entrance exam was indeed congruent with these academic needs or not: 
Table 1. Post-Graduate Students' Viewpoints regarding Academic Skills' Needs

\begin{tabular}{lll}
\hline skill & Item & Percent $(\%)$ \\
\hline Writing & Articles & 64.05 \\
& Emails and letters & 20.70 \\
& Translations & 5.29 \\
& Proposals and theses & 5.29 \\
& Reports & 2.88 \\
Reading & Power point slides & 2.40 \\
\cline { 2 - 3 } & Articles & 48.81 \\
& Books & 35.32 \\
& Texts & 6.34 \\
& Websites & 5.59 \\
& Theses and abstracts & 2.37 \\
& Newspapers & 1.18 \\
\cline { 2 - 3 } & Lectures and conference presentations & 25.25 \\
& No need & 25.25 \\
& Talks and conversations & 19.77 \\
& Films and documentaries & 18.32 \\
& News & 7.92 \\
& Online courses and classes & 3.46 \\
& Conferences and seminar presentations & 34.68 \\
& Conversation & 34.48 \\
& No need & 30.68 \\
\hline
\end{tabular}

The first of the five items inquired about the necessity of a writing skill component (which is non-existent in the current exam). The frequency analysis of the responses indicates that $65.71 \%$ of the participants preferred a writing section to be included in the exam while $34.29 \%$ did not. Those participants who favored the inclusion of this section to the exam asserted that,

- Writing articles is the most important need at the post-graduate level $(43.47 \%)$

- Writing is of vital importance in their academic life $(11.38 \%)$

- Writing is an instrument for staying in touch with the academic community $(10.86 \%)$

The participants who disapproved (34.29\%) the inclusion of a writing section to the General English Section of the Iranian National PhD Entrance Exam reasoned that:

- The educational system neither considers this skill as a priority in teaching nor is it included in the higher education syllabuses; therefore, it should not be tested (12.15\%)

- Writing is not an academic need, since they can get help from others to write $(12.06 \%)$

- The PhD Entrance exam is not the proper place to measure this skill (6.05\%)

- Grammar and vocabulary can account for the writing skill (4.03\%)

Nearly fifty percent $(49.70 \%)$ of the participants stated that the reading comprehension section of the exam matches their academic needs, while $50.30 \%$ were not satisfied with this section of the exam due to the following reasons:

- The reading passages are not field-specific so they do not match academic needs $(25.92 \%)$

- A multiple-choice test is not a valid measure of the academic reading skill (15.70\%)

- The reading passages are difficult $(8.68 \%)$

Similar to writing, listening comprehension is also currently excluded from the General English section of the Iranian National PhD Entrance Exam. Only $23.50 \%$ of the participants 
requested the addition of a listening component, while $76.50 \%$ did not deem this to be necessary. Those who favored the continued exclusion of listening from the exam commented that:

- There is no need for the English listening skill in the [Iranian] academic context $(42.37 \%)$

- Listening comprehension is not a priority compared with other skills (25.59\%)

- There are not enough proper facilities to measure this skill during the exam session $(4.44 \%)$

- The listening comprehension section is a source of stress in the exam (4.10\%)

Speaking is also currently excluded from the General English section of the Iranian National $\mathrm{PhD}$ Entrance Exam. On being asked for an opinion, $70.52 \%$ of the students claimed there is no need to include a speaking section to the PhD Entrance, whereas $28.95 \%$ considered the addition of a speaking section to the exam as compulsory. Those who were against the inclusion of this skill (70.52\%) reasoned as follows:

- There is no need for the English speaking skill in the [Iranian] academic context $(31.07 \%)$.

- Though it is an important skill, it is not a priority compared with other skills $(27.14 \%)$

- The subjective judgment of the raters may affect the scores (12.31\%)

The most popular reasons proposed by those who were in favor of the addition of a speaking section to the exam (28.95\%) were as follow:

- Speaking facilitates interaction with colleagues and other students worldwide (13.79\%)

- Speaking is one of the main language skills (11.59\%)

- Speaking helps strengthen our field-specific knowledge (3.57\%)

The last item in the questionnaire inquired about the degree of satisfaction of the students with the total test from an academic needs standpoint. $13.9 \%$ post-graduate participants of the study were satisfied with the exam, $40.4 \%$ believed that the exam did not match their academic needs. $34.3 \%$ considered the exam acceptable to some extent and finally, $10.8 \%$ were undecided.

\section{DISCUSSION and CONCLUSION}

The purpose of the present study was to discover if the language skills measured by the General English section of the Iranian National PhD Entrance Exam corresponded to the target language academic skills required at the post-graduate level in Iran. For this purpose, a data triangulation method was selected in which the data were collected from field-specialist informants in the academic disciplines of Humanities, Basic Sciences and Engineering, language-specialist informants, and the post-graduate students in the three mentioned disciplines in Iranian public universities.

The first research question was to find the field-specialists' opinions about the language skills that are most important at the post-graduate level and whether there was congruence between the exam and the required academic skills. The general conclusion from the field-specialist informants' opinions was that all language skills (listening, speaking, reading and writing) were imperative for post-graduate students. This conclusion is in line with Scarcella (2003) who believes that learners must develop an advanced level of proficiency in all language skills to have successful discipline-specific communication. However, reading and writing skills were considered as the most important skills at the post-graduate level, which is in line with Ostler's (1980) study who found that reading was the first important consideration in the academic 
context, and is also in sync with Saville-Troike (1984), who claimed that "the language skill which is most likely to develop. . . [academic] competence is writing" (p. 217). All in all, the field-specialist informants believed that the current exam does not meet the expectations of the post-graduate level. This is in line with what has been stated by Atai (2002a), who investigated the curriculum development of English for Specific Academic Purposes (ESAP) in Iran and concluded that, "ESAP curriculum development in Iran has not been conducted systematically and coherently.... the participants involved in the development and implementation of ESAP programs have typically done their tasks independently of each other" (p. 1). This has led to some participants suggesting the revision or the replacement of the current exam with international worldwide exams such as Academic IELTS.

The first research question also dealt with language-specialists. In general, the language specialists stated that all four language skills were imperative for a post-graduate student; however, in the academic context of Iran, reading and writing are more important. This incongruence might be justified by what has been proposed by Atai (2002b) who argues that the lack of rhetoric between the upper and lower layers of the English for academic purposes (EAP) curriculum results in confusion in EAP courses in Iran. Therefore, two language skills, as stated by language specialists are prioritized at the expense of others. Furthermore, language specialists believed that there was no difference among the Humanities, Basic Sciences and Engineering students in their academic language needs; however, in assigning the specifications of the skills, the genre and discourse specialties of different disciplines should be highlighted for students especially in reading their field-specific passages or writing abstracts or articles. This finding is in line with Calson (1983) who found that the type of required writing skills varies from discipline to discipline and the assessment criterion should be discourse rather than word or sentence. Moreover, Shih (1992) suggests that the academic writing skill involves not only formal schemata but also content schemata. With regard to congruity, the languagespecialist informants considered the test as a mismatch with the academic needs which, in turn, has rendered the test invalid. Kiany Mirhosseini, and Navidinia (2011) examined Iranian national documents to see if the literature on foreign language education policy has been taken into consideration in developing these documents. They concluded that the documents did not appear to be articulating coherent policies, and that there are occasional "mismatches among these documents" (p. 63). It is natural to expect that such mismatches would lead to similar problems in other areas as well, such as local assessment.

The second research question inquired about the language skills and congruity from the perspective of the post-graduate students. The order of the importance of skills was reading, writing, listening and speaking. Writing was mostly required for writing articles and email correspondences with researchers, professors and post-graduate students abroad. Reading skill is important for reading articles and books. Considering the listening skill, a successful and comprehensible presentation in conferences and seminars was the speaking need of postgraduate students.

As mentioned above, the General English section of the PhD Entrance Exam does not currently include writing, listening or speaking skills. The only measured skill is the reading comprehension skill. Therefore, this study also aimed at investigating if post-graduate students felt the need for the inclusion of these excluded skills, and whether the existing reading test matched their target academic needs. A large number of the participants requested the inclusion of writing skill to the exam since they need to write articles and to be in touch with their own academic community. The main reason for those who disapproved the inclusion of writing skill was that it was unfair to include a skill in the exam which had not been taught or prioritized in the academic context; therefore, it should not be tested. Students' claim might be justified through 'personnel policy' lens which examines whether there are language proficiency 
standards for teachers in academic contexts (Baldauf et al., 2010), and since in Iran, there is no systematic definition in the form of a formal evaluation scheme dealing with teachers' language proficiency standards or their professional knowledge of TLU tasks (Atai \& Mazlum, 2013), therefore writing skill is totally neglected. Furthermore, what has been stated by the postgraduate students regarding the exclusion of writing in the academic context of Iran has previously been mentioned by Eslami-Rasekh and Valizadeh (2004) and Farhady and Hadayati (2009) who state that though students show a great interest in communication skills, the grammar-translation, traditional and form-focused educational system with a great emphasis on grammar and translation has lessened their chance of using the language for communicative purposes. Furthermore, according to Clapham (2000), merely testing grammar is insufficient, and tests need to include writing tasks that are representative of the academic tasks. Considering the high percent of the students asking for the inclusion of a writing task, it is recommended to add a writing section to the future administrations of the exam. The type of writing tasks, as proposed by field and language specialist informants, can be similar to the IELTS academic exam.

The majority of the participants (76\%) preferred the exam not to have a listening comprehension section since they neither needed listening in their academic context, nor was it a priority comparing with other skills; also it was considered to be stressful. Similar to the listening skill, $70.52 \%$ of the participants were not in favor of a speaking section in the $\mathrm{PhD}$ Entrance Exam, reasoning that they did not need it and that the subjective judgment of the raters might affect their scores.

As stated before, reading comprehension is the only skill included in the General English section of the Iranian National $\mathrm{PhD}$ Entrance Exam; however, approximately half the participants claimed that the existing reading test does not match their academic needs while the other half believed it did. Therefore, it is recommended that the test developers do a thorough revision of the reading section of the exam to match the expectations of post-graduate students. The test designers are recommended to consider students' ideas, among others, in their test design, as suggested by Fox and Cheng (2007), who believe that underrepresentation of test-takers' perspectives in language assessment contexts is clearly problematic. These scholars emphasize including validation evidence from test-takers, such as an analysis of "how test takers interpret test constructs and the interaction between these interpretations, test design, and accounts of classroom practice" (Fox \& Cheng, 2007, p. 9).

\section{Implications of the study: Test reform}

What can be generally inferred from these triangulated data is that the current Iranian $\mathrm{PhD}$ Entrance Exam does not fully match the language needs of post-graduate students, nor does the curriculum that precedes it adequately prepare the students for target language academic English needs at the doctoral level. It would therefore seem that at least some faulty decisions lie with the curriculum behind the exam which might need deeper consideration or even change by the Ministry of Science, Research, and Technology, policy makers and the curriculum developers, as mentioned by $\mathrm{PhD}$ exam candidates regarding the writing skill, it seems totally unfair to include it in the exam though it is of utmost importance.

Tusi (1998) believes that one of the problems of mainstream ELT material developers in the ministries of education is that they simply do not identify learners' needs. In a similar vein in the Iranian context, Maftoon et al. (2010, p. 2) argue that, "curriculum developers. . . have almost certainly neglected to pay attention to students' needs and future demands." Atai and Mazlum (2013) believe that the gap between planning and practice levels is the result of a centralized policymaking approach of the Iranian officials in the Ministry of Research, Science and Technology. 
Fortunately, positive developments have recently been taking place in educational system of Iran, considering teaching English, to meet the target language academic needs of the students, such as changing the high school English books (which might be the root of the problem) as well as going over the old English teaching curricula at graduate and post graduate levels at the Ministry of Education and Ministry of Research, Science and Technology.

\section{ORCID}

\section{Shiela Kheirzadeh (D) https://orcid.org/0000-0003-4665-0554 \\ S. Susan Marandi (D) https://orcid.org/0000-0001-9852-1880 \\ Mansoor Tavakoli (D) https://orcid.org/0000-0002-4029-466X}

\section{REFERENCES}

Atai, M.R. (2002a). ESAP curriculum development in Iran: An incoherent educational experience. Journal of Persian Literature and Human Sciences of Tehran Teacher Training University, 1, 17-34.

Atai, M.R. (2002b). Iranian EAP programs in practice: A study of key methodological aspects. Sheikhbahaee Research Bulletin 1(2), 1-15.

Atai, M. R., \& Mazlum, F. English language teaching curriculum in Iran: Planning and practice. The Curriculum Journal 24(3), 389-411.

Baldauf, R.B., Li, M., \& Zhao, Sh. (2010). Language acquisition management inside and outside the school. In Handbook of educational linguistics. Oxford, UK: Blackwell.

Berendes, K., Vajjala, S., Meurers, D., Bryant, D., Wagner, W., Chinkina, M. (2018). Reading demands in secondary school: Does the linguistic complexity of textbooks increase with grade level and the academic orientation of the school track? Journal of Educational Psychology, 110, 518-543.

Benson, M. J. (1989). The academic listening task: A case study. TESOL Quarterly, 23(3), 421445.

Berman, R., \& Cheng, L. (2001). English academic language skills: Perceived difficulties by undergraduate and graduate students, and their academic achievement. Canadian Journal of Applied Linguistics, 4, 25-40.

Bridgeman, B., \& Carlson, S. B. (1983). Survey of academic writing tasks required of graduate and undergraduate foreign students. (TOEFL Research Report No. 15). Princeton, NJ: Educational Testing Service.

Butler, F. A., Lord, C., Stevens, R., Borrego, M., \& Bailey, A. L. (2004). An Approach to Operationalizing Academic Language for Language Test Development Purposes: Evidence from Fifth-Grade Science and Math. CSE Report 626. US Department of Education.

Canseco, G., \& Byrd, P. (1989). Writing required in graduate courses in business administration. TESOL Quarterly, 23(2), 305-316.

Chamot, A. U., \& O'Malley, J. M. (1994). The CALLA handbook: Implementing the cognitive academic language learning approach. Reading, MA: Addison-Wesley.

Cheng, L., Myles, J., \& Curtis, A. (2004). Targeting language support for non-native English speaking graduate students at a Canadian university. TESL Canada Journal, 22, 50-71.

Clapham, C. (2000). Assessment for academic purposes: where next? System, 28(4), 511-521.

Dudley-Evans, T., \& St John, M.J. (1998). Developments in English for Specific Purposes. Cambridge: Cambridge University Press.

Durkin, K. (2004). Challenges Chinese students face in adapting to academic expectations and teaching/learning styles of UK Masters courses, and how cross cultural understanding 
and adequate support might aid them to adapt. Discussion Paper. London: British Council.

Educational Testing Service (1990). TOEFL test and score manual. Princeton, NJ.

Eslami-Rasekh, Z. \& Valizadeh, K. (2004). Classroom activities viewed from different perspectives: Learners' voice vs. teachers' voice. TESL EJ, 8(3), 1-13.

Farhady, H. \& H. Hedayati. (2009). Language assessment policy in Iran. Annual Review of Applied Linguistics, 29, 132-141.

Ferris, D., \& Tagg, T. (1996). Academic listening/speaking tasks for ESL students: Problems, suggestions, and implications. TESOL Quarterly, 30(2), 297-320.

Field, J. (2011). Into the mind of the academic listener. Journal of English for Academic Purposes, 10, 102-112.

Flowerdew, J., \& Peacock, M., (2001). Research perspectives on English for Academic Purposes. Cambridge: Cambridge University Press.

Forey, G., \& Feng, D. (2016). Interpersonal meaning and audience engagement in academic presentations: A multimodal discourse analysis perspective. In K. Hyland \& P. Shaw (Eds.), The Routledge handbook of English for academic purposes (pp. 416-30). New York, NY: Routledge.

Fox, J., \& Cheng, L. (2007). Did we take the same test? Differing accounts of the Ontario Secondary School Literacy Test by first and second language test-takers. Assessment in Education: Principles, Policy and Practice, 14(1), 9-26.

Grabe, W. (2009). Reading in a second language: Moving from theory to practice. New York: Cambridge University Press.

Grabe, W., \& Stoller, F. L. (2011). Teaching and researching reading (2nd ed.). London, UK: Pearson Education.

Grabe, W., \& Zhang, C. (2013). Reading and writing together: A critical component of English for academic purposes teaching and learning. TESOL Journal, 4(1), 9-24.

Gottlieb, M. (2004). Overview. In WIDA consortium K -12 English language proficiency standards for English language learners: Frameworks for large-scale state and classroom assessment. Overview document. Madison: State of Wisconsin.

Gottlieb, M. H., \& Ernst-Slavit. G. (2013). Academic language a foundation for academic success in mathematics. In M. H. Gottlieb and G. Ernst-Slavit (Ed.), Academic language in diverse classrooms: mathematics, grades K-2: Promoting content and language learning (pp. 1-34). Corwin Press.

Huang, S. C. (2006). Reading English for academic purposes-What situational factors may motivate learners to read? System, 34(3), 371-383.

Hyland, K. (2006). English for Academic Purposes: An Advanced Resource Book. New York.

Leki, I., \& Carson, J. (1994). Students' perceptions of EAP writing instruction and writing needs across the disciplines. TESOL Quarterly, 28, 81-101.

Kiany, Gh., Mirhosseini, S.A., \& Navidinia. H. (2011). Foreign language education policies in Iran: Pivotal macro considerations. Journal of English Language Teaching and Learning, 53(222), 49-70.

Kim, S. (2006). Academic oral communication needs of East Asian international graduate students in non-science and non-engineering fields. English for Specific Purposes 25, 479-489.

Kuzborska, I. (2010). The relationship between EFL teachers' beliefs and practices in reading instruction to advanced learners of English in a Lithuanian University context. (Unpublished doctoral dissertation). University of Essex. Colchester, UK. 
Maftoon, P., M. Yazdani Moghaddam, H. Golebostan, \& S.R. Beh-Afarin. (2010). Privatization of English education in Iran: A feasibility study. The Electronic Journal for English as a Second Language, 13(4), 1-12.

Morell, T. (2007). What enhances EFL students' participation in lecture discourse? Student, lecturer and discourse perspectives. Journal of English for Academic Purposes, 6, 222-237.

Ostler, S. E. (1980). A survey of academic needs for advanced ESL. TESOL Quarterly, 4(4), 489-502.

Reid, I., Kirkpatric, A., \& Mulligan, D. (1998). Framing reading. Perth: National Center for English Language Teaching and Research with the Center for Literacy, Culture and Language Pedagogy at Curtin University of Technology.

Rosenfeld, M., Leung, S., \& Oltman, P. (2001). The reading, writing, speaking, and listening tasks important for academic success at the undergraduate and graduate levels. TOEFL monograph 21. Princeton, NJ: Educational Testing Service.

Rost, M. (2011). Teaching and researching listening (2nd ed.). Harlow, UK: Pearson

Ryan, K. (2002). Assessment validation in the context of high-stakes assessment. Educational Measurement: Issues and Practice, 21(1), 7-15.

Saville-Troike, M. (1984). What really matters in second language learning for academic achievement? TESOL Quarterly, 18 (2), 199-219.

Scarcella, R. (2003). Academic English: A Conceptual Framework (Technical report 2003-1). Santa Barbara, CA: Linguistic Minority Research Institute.

Schmitt, D., \& Hamp-Lyons, L. (2015). The need for EAP teacher knowledge in assessment. Journal of English for Academic Purposes, 18, 3-8.

Shafie, L., \& Nayan, S. (2011). The characteristics of struggling university readers and instructional approaches of academic reading in Malaysia. International Journal of Human Sciences [online]. 8, 1.

Shelyakina, O. K. (2010). Learner perceptions of their ESL training in preparation for university reading tasks (Master's thesis). Brigham Young University - Provo.

Shih, M. (1992). Beyond comprehension exercises in the ESL academic reading class. TESOL Quarterly, 26(2), 289-318.

Solomon, J., \& Rhodes, N. (1995). Conceptualizing academic language (Research Rep. No. 15). Santa Cruz: University of California, National Center for Research on Cultural Diversity and Second Language Learning.

Spaan, M. (2006). Test and item specifications development. Language Assessment Quarterly: An International Journal, 3(1), 71-79.

Swales, J. (1990). Genre analysis: English in academic and research settings. Cambridge: Cambridge University Press.

Zahedi, K., \& Shamsaee, S. (2012). Viability of construct validity of the speaking modules of international language examinations (IELTS vs. TOEFL iBT): evidence from Iranian testtakers. Educational Assessment, Evaluation and Accountability, 24(3), 263-277.

Zhu, W., \& Flaitz, J. (2005). Using focus group methodology to understand international students' academic language needs: A comparison of perspectives. TESL-EJ, 8(4), 1-11. 


\section{APPENDICES}

\section{Appendix A: Interview Questions}

1. Which language skills (listening, speaking, reading, writing and the two components of grammar and vocabulary) are required for $\mathrm{PhD}$ candidates? Why?

2. From among these skills, which is more important? Why?

3. Does the importance of the skills differ considering academic discipline (Humanities, Basic sciences, Engineering)? If yes, why?

4. On which skills the exam has focused? Why?

\section{Appendix B: Language Skills Questionnaire}

The following questionnaire is designed to evaluate the English language needs of the non-English major PhD candidates. Please read the question and answer.

1. Please rank the following language skills based on their order of importance (1 for the most important and 4 for the most important).

Listening.

Speaking

Reading.

Writing

2. For what do you use the writing skill? Please name.

3. Do you prefer the writing skill to be included in the PhD Entrance exam? Why?

4. For what do you use the reading skill? Please name.

5. Does the reading section of the $\mathrm{PhD}$ Entrance exam match your academic needs at PhD level? Why?

6. For what do you use the listening skill? Please name. 


\section{Do you prefer the listening skill to be included in the PhD Entrance exam? Why?}

8. For what do you use the speaking skill? Please name.

9. Do you prefer the speaking skill to be included in the PhD Entrance exam? Why?

10. From among the English language skills required at the $\mathrm{PhD}$ level, the followings can be named. Please rank them based on their importance (from 1, as the most important to 8, as the least important) and add any other skill you may find necessary.

Reading abstracts and papers

Taking notes in international conferences and seminars.

Presenting in international conferences.

Writing papers

Writing a review on articles and books

Summarizing......

Writing report.

Participating in scientific discussions.......

Etc.

11. In general, does the English section of the PhD Entrance exam match your PhD level English needs?

Yes.

No.

To some extent

No idea 